Review

\title{
COVID-19: what has been learned and to be learned about the novel coronavirus disease
}

\author{
Ye Yi, Philip N.P. Lagniton, Sen Ye, Enqin Li and Ren-He $\mathrm{Xu}^{\bowtie}$ \\ Institute of Translational Medicine, and Centre of Reproduction, Development and Aging, Faculty of Health Sciences, University of Macau, Taipa, Macau, China. \\ $\bowtie$ Corresponding author: Ren-He Xu, Faculty of Health Sciences, University of Macau, Taipa, Macau, China. Tel: 853-8822-4993; Fax: 853-8822-8345; Email \\ address: renhexu@um.edu.mo. \\ (c) The author(s). This is an open access article distributed under the terms of the Creative Commons Attribution License (https://creativecommons.org/licenses/by/4.0/). \\ See http://ivyspring.com/terms for full terms and conditions.
}

Received: 2020.02.20; Accepted: 2020.02.29; Published: 2020.03.15

\begin{abstract}
The outbreak of Coronavirus disease 2019 (COVID-19), caused by severe acute respiratory syndrome (SARS) coronavirus 2 (SARS-CoV-2), has thus far killed over 3,000 people and infected over 80,000 in China and elsewhere in the world, resulting in catastrophe for humans. Similar to its homologous virus, SARS-CoV, which caused SARS in thousands of people in 2003, SARS-CoV-2 might also be transmitted from the bats and causes similar symptoms through a similar mechanism. However, COVID-19 has lower severity and mortality than SARS but is much more transmissive and affects more elderly individuals than youth and more men than women. In response to the rapidly increasing number of publications on the emerging disease, this article attempts to provide a timely and comprehensive review of the swiftly developing research subject. We will cover the basics about the epidemiology, etiology, virology, diagnosis, treatment, prognosis, and prevention of the disease. Although many questions still require answers, we hope that this review helps in the understanding and eradication of the threatening disease.
\end{abstract}

Key words: Coronavirus, pneumonia, outbreak, SARS-CoV-2, COVID-19

\section{Introduction}

The Spring Festival on January 25, 2020 has become an unprecedented and unforgettable memory to all Chinese who were urged to stay indoors for all the holiday and for many weeks after due to the outbreak of a novel viral disease. The virus is highly homologous to the coronavirus $(\mathrm{CoV})$ that caused an outbreak of severe acute respiratory syndrome (SARS) in 2003; thus, it was named SARS-CoV-2 by the World Health Organization (WHO) on February 11, 2020, and the associated disease was named CoV Disease-19 (COVID-19) [1]. The epidemic started in Wuhan, China, and quickly spread throughout the entire country and to near 50 others all over the world. As of March 2, 2020, the virus has resulted in over 80,000 confirmed cases of COVID-19, with more than 40,000 patients discharged and over 3,000 patients who died. WHO warns that COVID-19 is "public enemy number 1 " and potentially more powerful than terrorism [2].

According to PubMed (https://www.ncbi.nlm. nih.gov/pubmed/), in less than two months, over 200 papers have been published on COVID-19 including its virology, epidemiology, etiology, diagnosis, and treatment since the first report on January 7, 2020 that determined the sequence of the virus isolated from multiple patients [3]. This review attempts to summarize the research progress in the new and swiftly developing subject area. Whenever possible, we will try to compare COVID-19 with SARS and another $\mathrm{CoV}$-caused disease, Middle East respiratory syndrome (MERS, an outbreak in 2012). We will also discuss what we have learned so far regarding the prevention and prognosis of the disease as well as some remaining yet urgent questions.

\section{The outbreak}

CoVs have been traditionally considered nonlethal pathogens to humans, mainly causing approximately $15 \%$ of common colds [4]. However, in this century, we have encountered highly pathogenic human CoVs twice, i.e., SARS-CoV and MERS-CoV, which caused an outbreak originally in China in 2003 
and Saudi Arabia in 2012, respectively, and soon spread to many other countries with horrible morbidity and mortality [5]. Therefore, the current COVID-19 is the third CoV outbreak in the recorded history of humans.

As shown in Fig. 1, clusters of pneumonia that had unknown origins were first reported from Wuhan on December 31, 2019 to the China National Health Commission [6]. Seven days later the sequence of the $\mathrm{CoV}$ was released [7]. On January 15, 2020 the first fatal case from Wuhan was reported [6]. Meanwhile, the epidemic rapidly spread to the neighboring cities, provinces, and countries. On January 20, the infection of health-care providers was reported, suggesting that human-to-human transmission was possible [8]. On January 23, the city of Wuhan was locked down with all its public transportation stopped. On January 24 the first clinical study on the disease reported that, out of 41 patients with confirmed cases, only 21 had direct contact with the Wuhan seafood market that was considered the starting site of the infection from an unknown animal source [6]. On January 30, WHO declared the outbreak a global health emergency. By the time of this report, the disease has already spread throughout China and near 50 other countries all over the world (Fig. 2). As the situation is rapidly evolving, the final scope and severity of the outbreak remain to be determined.
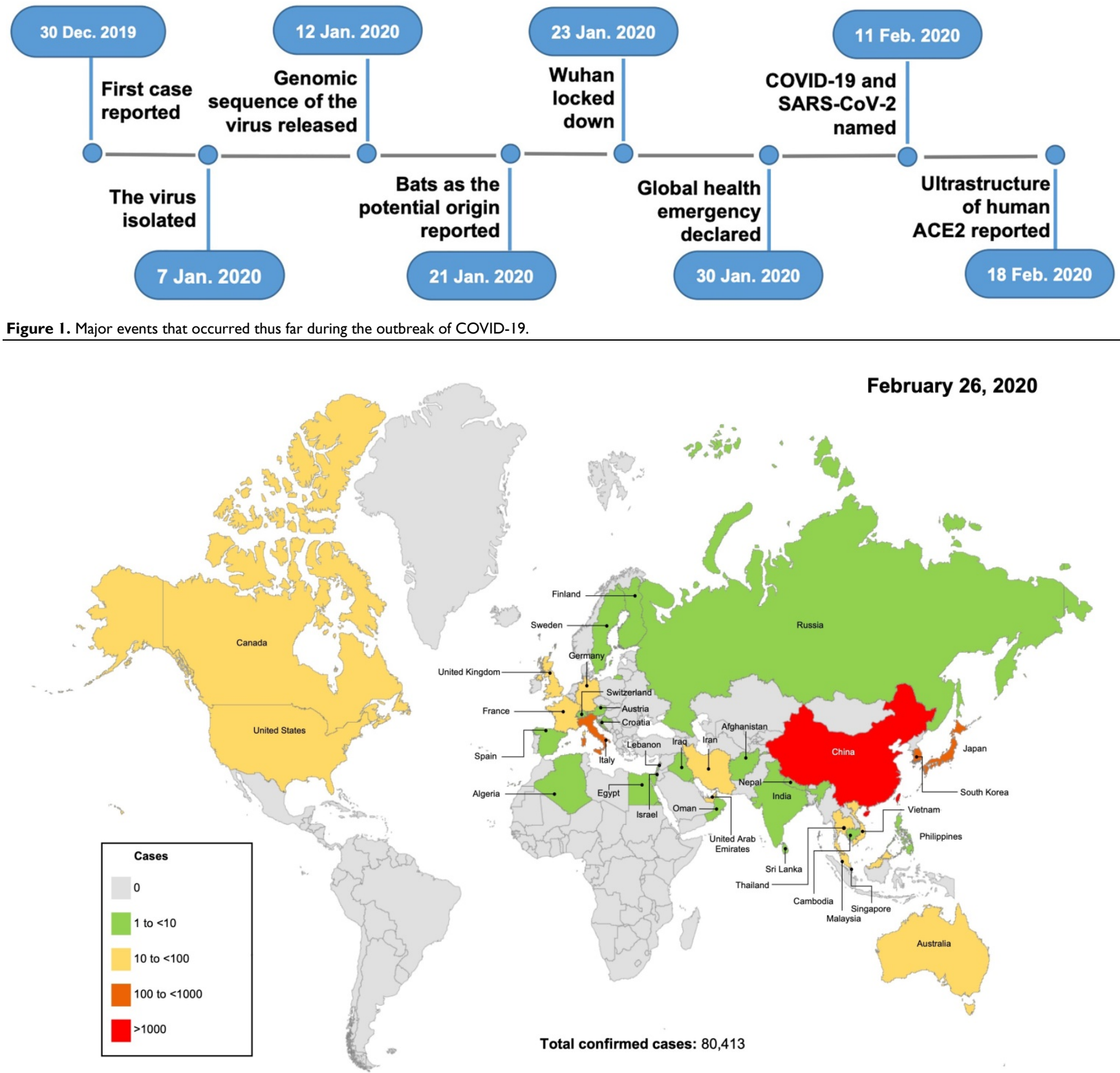

February 26, 2020

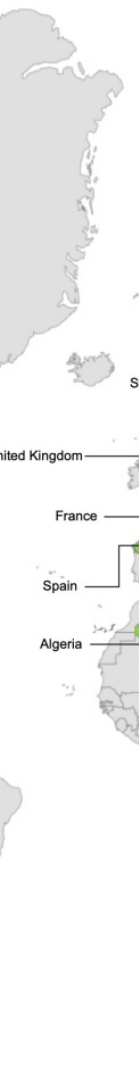

Total confirmed cases: 80,413

Figure 2. Worldwide distribution of COVID-19 cases on 26 Feb. 2020, according to a coronavirus monitoring system of Johns Hopkins University [9,10]. 
On February 11, 2020, a multi-center study on 8,866 patients including 4,021 confirmed COVID-19 patients presented a more updated illustration of the epidemic as follows (https://mp.weixin.qq.com/s/ UlBi-HX_rHPXa1qHA2bhdA).

- SARS-CoV-2 infected people of all ages, but mainly at the age of 30-65. Almost half (47.7\%) of the infected individuals were over 50 years old, very few were under 20, and only 14 infected individuals were under the age of 10 .

- SARS-CoV-2 infected more men $(0.31 / 100,000)$ than women $(0.27 / 100,000)$.

- COVID-19 expanded in clusters mainly in and around Hubei.

- COVID-19 took an average of 5 (2-9) days from onset to diagnosis. The average incubation period was 4.8 (3.0-7.2) days. The average time from onset to death was 9.5 (4.8-13) days.

- The basic reproductive number (R0) was 3.77 (95\% CI: 3.51-4.05), and the adjusted R0 was 2.23-4.82.

- The number of infected people increased exponentially before 23 Jan. 2020, matching the time of massive transportation before the Spring Festival in China.

- The mortality of patients with confirmed cases was $1.44 \%$ (95\% CI: $1.10-1.86 \%$ ), and the adjusted mortality of all the patients was 3.06\% (95\% CI: $2.02-4.59 \%)$

- Three major risk factors for COVID-19 were sex (male), age $(\geq 60)$, and severe pneumonia.

\section{SARS-CoV-2}

\section{Etiology}

CoVs are a subfamily of large and enveloped viruses containing a single strand of sense RNA. They can be divided into four genera, i.e., alpha, beta, gamma, and delta, of which alpha- and beta-CoVs are known to infect humans [11]. The envelope spike (S) glycoprotein binds to its cellular receptors angiotensin-converting enzyme 2 (ACE2) and dipeptidyl peptidase 4 (DPP4) for SARS-CoV and MERS-CoV, respectively, and then membrane fusion occurs [12]. The viral RNA genome is released into the cytoplasm; after replication of the viral genome, genomic RNA accompanied by envelope glycoproteins and nucleocapsid proteins forms virion-containing vesicles, which then fuse with the plasma membrane to release the virus [13].

The first genomic sequence of SARS-CoV-2 was reported on January 10, 2020 [3]. SARS-CoV-2 was found to be a new type of beta-CoV with more than
99.98\% genetic identity among 10 sequenced samples collected from the original site of the outbreak, the Huanan Seafood Market in Wuhan. SARS-CoV-2 is genetically more similar to SARS-CoV than to MERS-CoV [14-16]. Through transmission electron microscopy, SARS-CoV-2 particles were found in ultrathin sections of human airway epithelium [17]. Human ACE2 was found to be a receptor for SARS$\mathrm{CoV}-2$ as well as SARS-CoV $[16,18,19]$. However, the $S$ protein of SARS-CoV-2 binds to human ACE2 more weakly than that of SARS-CoV, which is coincident with the fact that SARS-CoV-2 causes less severe infection in patients than SARS-CoV [14].

SARS-CoV-2 can also form a novel short protein encoded by orf $3 b$ and a secreted protein encoded by orf8. The orf3b of SARS-CoV-2 may play a role in the viral pathogenicity and inhibit the expression of IFN $\beta$; however, orf8 does not contain any known functional domain or motif [20]. On February 18, 2020, Zhou, et al., reported the cryo-EM structure of the full-length human ACE2 at $2.9 \AA$ resolution in complex with the amino acid transporter $\mathrm{B}^{0} \mathrm{AT} 1$ [21]. They found that the complex, which had open and closed conformations, was assembled as a dimer and the ACE2-B ${ }^{0} \mathrm{AT} 1$ complex can bind two $S$ proteins, which provides evidence for $\mathrm{CoV}$ recognition and infection. $\mathrm{B}^{0} \mathrm{AT} 1$ may become a therapeutic target for drug screening to suppress SARS-CoV-2 infection.

\section{The origin and intermediate host}

It has been known that both SARS-CoV and MERS-CoV originated from bats and were transmitted to humans via civet cats and camels, respectively. Through a phylogenetic comparison of SARS-CoV-2 with other CoVs, bats were considered the native host of SARS-CoV-2 as the new virus is $96 \%$ identical to two SARS-like CoVs from bats called bat-SL-CoVZX45 and bat-SL-CoVZX21 [14-16,19]. However, what intermediate host helped the virus cross the species barrier to infect humans remains unknown, and the transmission route is yet to be elucidated. Ji, et al., proposed snakes as a carrier of the virus from bats to humans which involved homologous recombination within the $S$ protein [22]. According to a study, researchers in Guangzhou, China, suggested that pangolins - long-snouted, anteating mammals often used in traditional Chinese medicine - are the potential intermediate host of SARS-CoV-2 based on $99 \%$ genetic homology in a $\mathrm{CoV}$ discovered in pangolins and SARS-CoV-2 [23]. However, $1 \%$ difference spread all over two genomes is still a big difference; thus, conclusive results for concrete evidence are awaited (Fig. 3). 


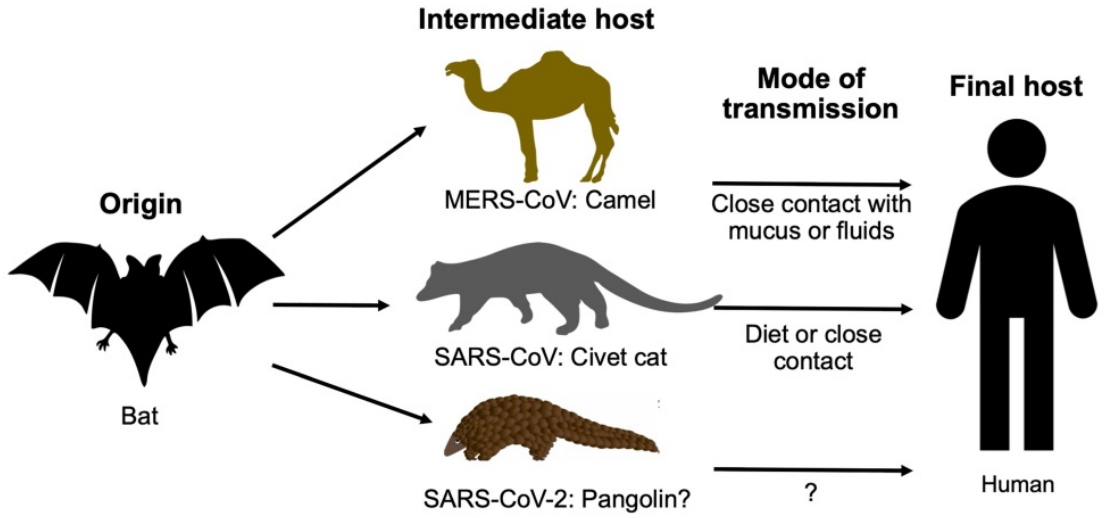

Figure 3. The origins and intermediate hosts of SARS-CoV-2, SARS-CoV, and MERS-CoV.

SARS-CoV (\& SARS-CoV-2?)

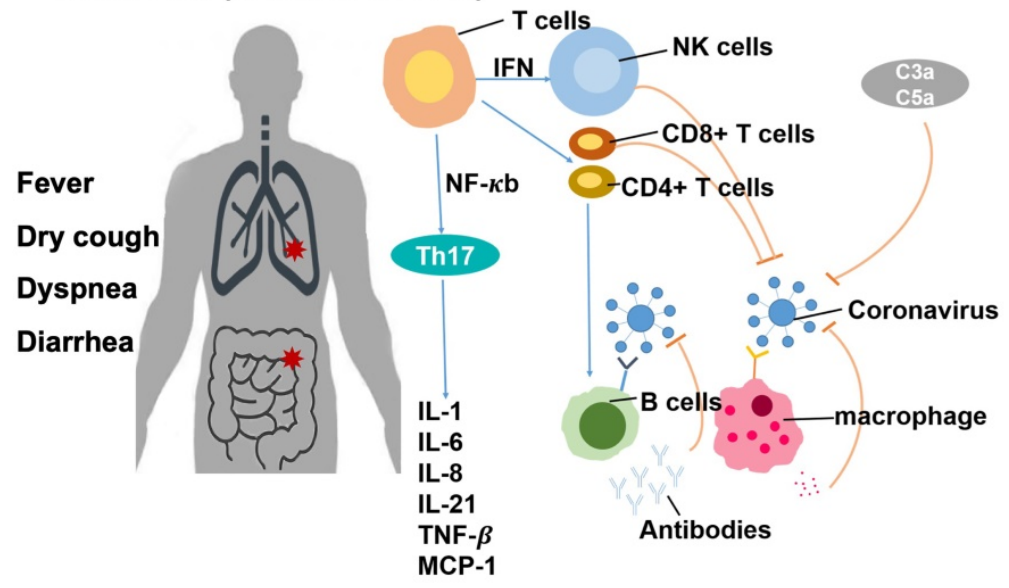

MERS-CoV

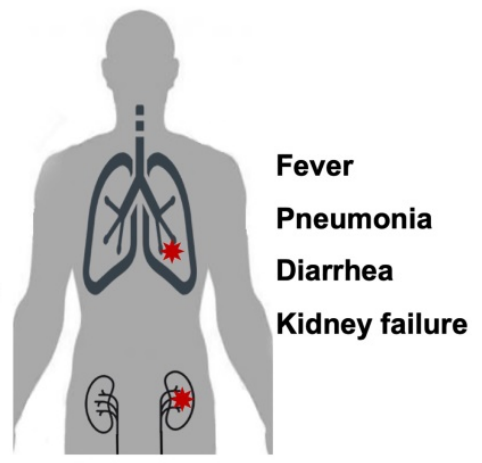

Figure 4. Immune response of the host to coronavirus infection [4, 32-34].

\section{Physicochemical properties}

The physicochemical properties of SARS-CoV-2 are largely not yet known. SARS-CoV and MERS-CoV can survive in vitro for 48 hours in a dry environment and up to 5 days under $20^{\circ} \mathrm{C}$ and $40 \%-50 \%$ humidity [24-26]. SARS-CoV-2 may possess similar properties. It has been reported that SARS-CoV-2 is sensitive to ultraviolet rays and heat at $56^{\circ} \mathrm{C}$ for 30 minutes; ether, $75 \%$ ethanol, chlorine-containing disinfectant, peracetic acid, chloroform, and other fatty solvents, but not chlorhexidine, can effectively inactivate the virus [27].

\section{Immune responses to CoVs}

The entire human population generally lacks immunity to SARS-CoV-2 and hence is susceptible to the novel virus. Currently, no detailed study has been reported regarding the immunological response to SARS-CoV-2. Thus, we can only refer to previous studies on other $\mathrm{CoVs}$, especially SARS-CoV and MERS-CoV (Fig. 4). In general, after a virus invades the host, it is first recognized by the host innate immune system through pattern recognition receptors (PRRs) including C-type lectin-like receptors, Toll-like receptor (TLR), NOD-like receptor (NLR), and RIG-Ilike receptor (RLR) [28]. Through different pathways, the virus induces the expression of inflammatory factors, maturation of dendritic cells, and synthesis of type I interferons (IFNs) which limit the spreading of the virus and accelerate macrophage phagocytosis of viral antigens [28]. However, the N protein of SARS$\mathrm{CoV}$ can help the virus escape from the immune responses [29].

Soon, the adaptive immune response joins the fight against the virus. T lymphocytes including $\mathrm{CD} 4^{+}$ and $\mathrm{CD}^{+} \mathrm{T}$ cells play an important role in the defense. $\mathrm{CD}^{+} \mathrm{T}$ cells stimulate $\mathrm{B}$ cells to produce virus-specific antibodies, and $\mathrm{CD} 8^{+} \mathrm{T}$ cells directly kill virus-infected cells. $\mathrm{T}$ helper cells produce proinflammatory cytokines to help the defending cells. However, $\mathrm{CoV}$ can inhibit $\mathrm{T}$ cell functions by inducing apoptosis of $\mathrm{T}$ cells. The humoral immunity including complements such as $\mathrm{C} 3 \mathrm{a}$ and $\mathrm{C} 5 \mathrm{a}$ and antibodies is also essential in combating the viral infection [30,31]. For example, antibodies isolated from a recovered patient neutralized MERS-CoV [32]. On the other hand, an overreaction of the immune system generates a large number of free radicals locally that can cause severe damages to the lungs and 
other organs, and, in the worst scenario, multi-organ failure and even death [33].

\section{Clinical features}

\section{The incubation periods}

The SARS-CoV-2 infection, featured by clustering onset, is more likely to affect elderly people with comorbidities and pregnant women [8]. It is common that for people who are exposed to a large number of viruses or whose immune functions are compromised, they have higher chance to be infected than others. The estimated mean incubation period of SARS-CoV-2 is 1-14 days, mostly 3-7 days based on a study of the first 425 cases in Wuhan [36]. However, a study on 1,099 cases demonstrates that the incubation period was 3 days on average and ranged from 0 to 24 days [8]. A more recent study, as described above, demonstrates that the incubation period was 4.8 (3.0-7.2) days based on the demography of 8,866 cases [37]. It is very important for health authorities to adjust the effective quarantine time based on the most accurate incubation period, thus preventing infected but symptomless people from transmitting the virus to others [38]. As a common practice, individuals exposed to, or infected by, the virus are usually required to be quarantined for 14 days. Should the quarantine time be extended to 24 days?

\section{Symptoms}

Fever is often the major and initial symptom of COVID-19, which can be accompanied by no symptom or other symptoms such as dry cough, shortness of breath, muscle ache, dizziness, headache, sore throat, rhinorrhea, chest pain, diarrhea, nausea, and vomiting. Some patients experienced dyspnea and/or hypoxemia one week after the onset of the disease [8]. In severe cases, patients quickly progressed to develop acute respiratory syndrome, septic shock, metabolic acidosis, and coagulopathy. Patients with fever and/or respiratory symptoms and acute fever, even without pulmonary imaging abnormalities, should be screened for the virus for early diagnosis [39-41].

A demographic study in late December of 2019 showed that the percentages of the symptoms were $98 \%$ for fever, $76 \%$ for dry cough, $55 \%$ for dyspnea, and $3 \%$ for diarrhea; $8 \%$ of the patients required ventilation support [42]. Similar findings were reported in two recent studies of a family cluster and a cluster caused by transmission from an asymptomatic individual $[43,44]$. Comparably, a demographic study in 2012 showed that MERS-CoV patients also had fever (98\%), dry cough $(47 \%)$, and dyspnea $(55 \%)$ as their main symptoms. However, $80 \%$ of them required ventilation support, much more than COVID-19 patients and consistent with the higher lethality of MERS than of COVID-19. Diarrhea $(26 \%)$ and sore throat (21\%) were also observed with MERS patients. In SARS patients, it has been demonstrated that fever (99\%-100\%), dry cough (29\%-75\%), dyspnea $(40 \%-42 \%)$, diarrhea (20-25\%), and sore throat (13-25\%) were the major symptoms and ventilation support was required for approximately $14 \%-20 \%$ of the patients [45].

By February 14, the mortality of COVID-19 was $2 \%$ when the confirmed cases reached 66,576 globally. Comparably, the mortality of SARS by November 2002 was $10 \%$ of 8,096 confirmed cases [46]. For MERS, based on a demographic study in June 2012, the mortality was $37 \%$ of 2,494 confirmed cases [47]. An earlier study reported that the R0 of SARS-CoV-2 was as high as 6.47 with a $95 \%$ confidence interval (CI) of 5.71-7.23 [48], whereas the R0 of SARS-CoV only ranged from 2 to 4 [49]. A comparison of SARS$\mathrm{CoV}-2$ with MERS-CoV and SARA-CoV regarding their symptoms, mortality, and $\mathrm{R} 0$ is presented in Table 1 . The above figures suggest that SARS-CoV-2 has a higher ability to spread than MERS-CoV and SARS-CoV, but it is less lethal than the latter two [6]. Thus, it is much more challenging to control the epidemic of SARS-CoV-2 than those of MERS-CoV and SARS-CoV.

Table 1. Comparison of SARS-CoV-2 with SARS-CoV and MERS-CoV

\begin{tabular}{lllll}
\hline Comparison items & SARS-CoV-2 & MERS-CoV & SARS-CoV & Reference \\
\hline Characteristics & Dec. $2020-$ Feb. 2020 & Sept. 2012 & Dec. 2003 \\
Date extracted from & Wuhan, China & Jeddah, Saudi Arabia & Guangdong China \\
Place of origin & $56(22-92)$ & $56(14-94)$ & $39.9(1-91)$ \\
Age range & $1: 3: 1$ & $3.3: 1$ & 1.1 .25 \\
Male/Female sex ratio & $2 \%$ & $34 \%$ & $9.6 \%$ & 8096 \\
Mortality rate & 24554 & 2494 & $0.86-1.88$ & $4.4-6.9$ \\
Confirmed cases (Global) & $4.7-6.6$ & $0.45-0.91$ & \\
$R_{0}$ & $7-14$ & $5.0-6.9$ & $99-100 \%$ & {$[37,42]$} \\
Incubation period (day) & & & $29-75 \%$ & {$[6,34,37]$} \\
Symptoms & $258(93 \%)$ & $98 \%$ & $40-42 \%$ & \\
Fever & $194(70 \%)$ & $47 \%$ & \\
Dry cough & $96(35 \%)$ & $72 \%$ & \\
Dyspnea & & &
\end{tabular}




\begin{tabular}{|c|c|c|c|c|}
\hline Comparison items & SARS-CoV-2 & MERS-CoV & SARS-CoV & Reference \\
\hline Diarrhea & $17(6 \%)$ & $26 \%$ & $20-25 \%$ & \\
\hline Sore throat & $10(4 \%)$ & $21 \%$ & $13-25 \%$ & \\
\hline
\end{tabular}

\section{Diagnosis}

\section{Patient history}

Clustered onset often happens in the same family or from the same gathering or vehicle such as a cruise ship. Patients often have a history of travel or residence in Wuhan or other affected areas or contact with infected individuals or patients in the recent two weeks before the onset [50]. However, it has been reported that people can carry the virus without symptoms longer than two weeks and cured patients discharged from hospitals can carry the virus again [51], which sends out an alarm to increase the time for quarantine.

\section{Laboratory results}

Patients have normal or reduced number of peripheral white blood cells (especially lymphocytes) at the early stage. For example, lymphopenia with white blood cell count $<4 \times 10^{9} / \mathrm{L}$ including lymphocyte count $<1 \times 10^{9} / \mathrm{L}$, and elevated aspartate aminotransferase levels and viremia were found in 1,099 COVID-19 patients [8]. The levels of liver and muscle enzymes and myoglobin were increased in the blood of some patients, and C-reactive protein and erythrocyte sedimentation were increased in the blood of most patients [52]. In patients with severe cases, the level of D-dimer, a fibrin degradation product present in the blood, was elevated, and lymphocyte count was progressively reduced [34].

\section{Radiography}

Abnormalities in chest radiography are found in most COVID-19 patients and featured by bilateral patchy shadows or ground glass opacity in the lungs. Patients often develop an atypical pneumonia, acute lung injury, and acute respiratory distress syndrome (ARDS) [34]. When ARDS happens, uncontrolled inflammation, fluid accumulation, and progressive fibrosis severely compromise the gas exchange. Dysfunction of type-I and type-II pneumocytes decreases the surfactant level and increases surface tension, thus reducing the ability of the lungs to expand and heightening the risk of lung collapse [53, 54]. Therefore, the worst chest radiographic findings often parallel the most severe extent of the disease [55].

\section{Pathology}

On February 18, 2020, the first pathological analysis of COVID-19 demonstrated the desquamation of pneumocytes, hyaline membrane formation, and interstitial lymphocyte infiltration, and multinucleated syncytial cells in the lungs of a patient who died of the disease, consistent with the pathology of viral infection and ARDS [56] and similar to that of SARS and MERS patients $[57,58]$.

\section{Nuclear acid assays}

The detection of SARS-CoV-2 RNA via reversetranscriptase polymerase chain reaction (RT-PCR) was used as the major criteria for the diagnosis of COVID-19. However, due to the high false-negative rate, which may accelerate the epidemic, clinical manifestations started to be used for diagnosis (which no longer solely relied on RT-PCR) in China on February 13, 2020. A similar situation also occurred with the diagnosis of SARS [59]. Therefore, a combination of disease history, clinical manifestations, laboratory tests, and radiological findings is essential and imperative for making an effective diagnosis. On February 14, 2020, the Feng Zhang group described a protocol of using the CRISPR-based SHERLOCK technique to detect SARSCoV-2, which detects synthetic SARS-CoV-2 RNA fragments at $20 \times 10^{-18} \mathrm{~mol} / \mathrm{L}$ to $200 \times 10^{-18} \mathrm{~mol} / \mathrm{L}$ (10-100 copies per microliter of input) using a dipstick in less than an hour without requiring elaborate instrumentation [60]. Hopefully, the new technique can dramatically enhance the sensitivity and convenience if verified in clinical samples.

\section{Treatment}

Due to the lack of experience with the novel $\mathrm{CoV}$, physicians can mainly provide supportive care to COVID-19 patients, while attempting a variety of therapies that have been used or proposed before for the treatment of other $\mathrm{CoVs}$ such as SARS-CoV and MERS-CoV and other viral diseases (Table 2). These therapies include current and potential treatments with antiviral drugs, immunosuppressants, steroids, plasma from recovered patients, Chinese medicine, and psychological support. Even plasma from recovered patients was proposed to be used for treatment [61]. Pharmaceutical companies are racing to develop antibodies and vaccines against the virus [62].

\section{Supportive care}

SARS-CoV-2 mainly attacks the lungs in the beginning and probably also attacks, to a lesser degree, other organs that express ACE2, such as the 
gastrointestinal system and the kidneys. Nevertheless, respiratory dysfunction and failure are the major threat to the patients and the major cause of death. Thus, respiratory support is critical to relieve the symptoms and save lives and includes general oxygen therapy, high-flow oxygen, noninvasive ventilation, and invasive mechanical ventilation depending on the severity of the disease. Patients with severe respiratory symptoms have to be supported by extracorporeal membrane oxygenation (ECMO), a modified cardiopulmonary bypass technique used for the treatment of life-threatening cardiac or respiratory failure. In addition, the maintenance of electrolyte balance, the prevention and treatment of secondary infection and septic shock, and the protection of the functions of the vital organs are also essential for SARS-CoV-2 patients [7].

Table 2. Treatments of COVID-19

\begin{tabular}{lll}
\hline Treatment & Efficacy & References \\
\hline $\begin{array}{l}\text { General oxygen therapy, } \\
\text { high-flow oxygen/noninvasive } \\
\text { ventilation, and invasive }\end{array}$ & Respiratory supports & {$[7]$} \\
$\begin{array}{l}\text { mechanical ventilation, } \\
\text { conservation fluid management, } \\
\text { management of septic shock, } \\
\text { infection control }\end{array}$ & & \\
$\begin{array}{l}\text { Antiviral therapy } \\
\text { Remdesivir }\end{array}$ & Reduce the viral load & {$[63]$} \\
Steroids & - & {$[64]$} \\
& $\begin{array}{l}\text { Reduce the severity of } \\
\text { inflammatory damage }\end{array}$ & {$[65]$} \\
Psychological supports & $\begin{array}{l}\text { Relieve stress and improve } \\
\text { mental health }\end{array}$ & {$[66]$} \\
\hline
\end{tabular}

\section{Tackling cytokine storms}

It has been known that a cytokine storm results from an overreaction of the immune system in SARS and MERS patients [33]. Cytokine storm is a form of systemic inflammatory response featured by the release of a series of cytokines including TNFa, IL-1 $\beta$, IL-2, IL-6, IFNa, IFN $\beta$, IFN $\gamma$, and MCP-1. These cytokines induce immune cells to release a vast number of free radicals which are the major cause of ARDS and multiple organ failure [67]. Immunosuppression is essential in the treatment of cytokine storms, especially in severe patients.

Corticosteroids and tocilizumab, an anti-IL6 monoclonal antibody, have been used to treat cytokine storm [68]. Other immunosuppression treatments for cytokine storm include the modulation of $\mathrm{T}$ cell-directed immune response; the blockade of IFN- $\gamma$, IL-1, and TNF; JAK inhibition [69]; blinatumomab [70]; suppressor of cytokine signaling 4 [71]; and HDAC inhibitors [72].

Steroids, as immunosuppressants, were widely used in the treatment of SARS to reduce the severity of inflammatory damage [65]. However, steroids at high dosages were not beneficial to severe lung injury in SARS and COVID-19 patients [59,73]. Instead, they may cause severe side effects, especially avascular osteonecrosis, dramatically affecting the prognosis [74]. Nevertheless, short courses of corticosteroids at low-to-moderate doses have been recommended to be used prudently for critically ill COVID-19 patients [75].

\section{Antiviral therapy}

At the time of writing, no effective antiviral therapy has been confirmed. However, intravenous administration with remdesivir, a nucleotide analog, has been found to be efficacious in an American patient with COVID-19 [64]. Remdesivir is a novel antiviral drug developed by Gilead initially for the treatment of diseases caused by Ebola and Marlburg viruses [76]. Later, remdesivir also demonstrated possible inhibition of other single stranded RNA viruses including MERS and SARS viruses [77,78]. Based on these, Gilead has provided the compound to China to conduct a pair of trials on SARS-CoV-2infected individuals [79], and the results are highly anticipated.

In addition, baricitinb, interferon- $\alpha$, lopinavir/ ritonavir, and ribavirin have been suggested as potential therapies for patients with acute respiratory symptoms [80,81]. Diarrhea, nausea, vomiting, liver damage, and other adverse reactions can occur following combined therapy with lopinavir/ritonavir [80]. The interaction of these treatments with other drugs used in the patients should be monitored carefully.

\section{Plasma from recovered patients and antibody generation}

The collection of the blood from patients who recovered from a contagious disease to treat other patients suffering from the same disease or to protect healthy individuals from catching the disease has a long history [82]. Indeed, recovered patients often have a relatively high level of antibodies against the pathogen in their blood. Antibodies are an immunoglobulin (Ig) produced by B lymphocytes to fight pathogens and other foreign objects and they recognize unique molecules in the pathogens and neutralize them directly [83]. Based on this, plasma was collected from the blood of a group of patients who recovered from COVID-19 and was injected into 10 seriously ill patients. Their symptoms improved within 24 hours, accompanied by reduced inflammation and viral loads and improved oxygen saturation in the blood. However, verification and clarification are necessary to propose the method for 
large-scale use before specific therapies are not yet developed.

In addition, given the therapeutic effects, some disadvantages associated with the plasma should be considered carefully. For example, antibodies can overstimulate the immune response and cause cytokine release syndrome, which is potentially a life-threatening toxicity [84]. The concentration of antibodies in the blood is usually low, and the demand for the plasma is large to treat critically ill patients. It is difficult to develop and produce specific antibodies rapidly enough to fight against a global epidemic [62]. Thus, it is more critical and practical to isolate B cells from recovered patients and identify the genetic codes encoding effective antibodies or screen for effective antibodies against essential proteins of the virus. This way, we can readily scale up the production of the antibodies.

\section{Traditional Chinese medicine (TCM)}

TCM has been used to treat a variety of diseases in China for thousands of years. However, its effects largely rely on a combination of multiple components in a formula that varies depending on the diagnosis of a disease based on the theories of TCM. Most of the effective components remain unknown or are vague as it is difficult to extract and verify such components or their optimal combinations. Currently, due to the lack of effective and specific therapy for COVID-19, TCM has become one of the major alternative treatments for patients with light to moderate symptoms or for those who have recovered from severe stages [85]. For example, Shu Feng Jie Du capsules and Lian Hua Qing Wen capsules were found to be effective for COVID-19 treatment [86]. Top cure rates in the treatment of COVID-19 patients were observed in several provinces in China that used TCM in $87 \%$ of their patients, including Gansu $(63.7 \%)$, Ningxia (50\%), and Hunan (50\%), whereas Hubei province, which used TCM in only approximately $30 \%$ of its COVID-19 patients, had the lowest cure rate $(13 \%)$ [87]. However, this is quite a rough comparison as many other impact factors such as the number and severity of the patients should be included in the evaluation.

On February 18, 2020, Boli Zhang and coworkers published a study to compare western medicine (WM) treatment alone with combined treatment of WM and TCM [88]. They found that the times needed for body temperature recovery, symptom disappearance, and hospitalization were remarkably shorter in the WM+TCM group than in the WM only group. Most impressively, the rate for symptomatic worsening (from light to severe) was remarkably lower for the WM+TCM group than for the WM only group $(7.4 \%$ versus $46.2 \%)$ and the mortality was lower in the WM+TCM group than WM only group $(8.8 \%$ versus $39 \%)$. Nevertheless, the efficacy and safety of TCM still await more well-controlled trials at larger scales and in more centers. It would also be intriguing to characterize the mechanism of actions and clarify the effective components of TCM treatments or their combinations if possible.

\section{Mental health care}

Patients with suspected or confirmed COVID-19 mostly experience great fear of the highly contagious and even fatal disease, and quarantined people also experience boredom, loneliness, and anger. Furthermore, symptoms of the infection such as fever, hypoxia, and cough as well as adverse effects of the treatments such as insomnia caused by corticosteroids can lead to more anxiety and mental distress. In the early phase of the SARS outbreak, a range of psychiatric morbidities including persistent depression, anxiety, panic attacks, psychomotor excitement, psychotic symptoms, delirium, and even suicidality were reported $[89,90]$. Mandatory contact tracing and quarantine, as a part of the public health responses to the COVID-19 outbreak, can make people more anxious and guilty about the effects of the contagion, quarantine, and stigma on their families and friends [66].

Thus, mental health care should be provided to COVID-19 patients, suspected individuals, and people in contact with them as well as the general public who are in need. The psychological support should include the establishment of multidisciplinary mental health teams, clear communications with regular and accurate updates about the SARS-CoV-2 outbreak and treatment plans and the use of professional electronic devices and applications to avoid close contact with each other [66].

\section{Vaccination}

Effective vaccines are essential for interrupting the chain of transmission from animal reservoirs and infected humans to susceptible hosts and are often complementary to antiviral treatment in the control of epidemics caused by emerging viruses. Efforts have been made to develop $S$ protein-based vaccines to generate long-term and potent neutralizing antibodies and/or protective immunity against SARS-CoV [81, 91]. Live-attenuated vaccines have been evaluated in animal models for SARS [92]. However, the in vivo efficacy of these vaccine candidates in elderly individuals and lethal-challenge models and their protection against zoonotic virus infection have yet to be determined before a clinical study is initiated. This is probably because SARS died down 17 years ago 
and no new case has been reported since.

In contrast, sporadic cases and clusters of MERS continue to occur in the Middle East and spread to other regions owing to the persistence of zoonotic sources in endemic areas. Vaccination strategies have been developed for MERS by using inactivated virus, DNA plasmids, viral vectors, nanoparticles, virus-like particles and recombinant protein subunits and some have been evaluated in animal models [93]. The development of a safe and effective vaccine against SARS-CoV-2 for non-immune individuals is an urgent and critical task for controlling the ongoing epidemic. However, it is challenging to overcome the difficulty because of the long period of time (averaged 18 months) needed for vaccine development and the dynamic variations of $\mathrm{CoVs}$.

\section{Prognosis}

\section{Prognosis of patients}

As a novel disease, COVID-19 has just started to manifest its full clinical course throughout thousands of patients. In most cases, patients can recover gradually without sequelae. However, similar to SARS and MERS, COVID-19 is also associated with high morbidity and mortality in patients with severe cases. Therefore, building a prognosis model for the disease is essential for health-care agencies to prioritize their services, especially in resourceconstrained areas. Based on clinical studies reported thus far, the following factors may affect or be associated with the prognosis of COVID-19 patients (Table 3):

- Age: Age was the most important factor for the prognosis of SARS [99], which is also true for COVID-19. COVID-19 mainly happened at the age of $30-65$ with $47.7 \%$ of those patients being over 50 in a study of 8,866 cases as described above [37]. Patients who required intensive care were more likely to have underlying comorbidities and complications and were significantly older than those who did not (at the median age of 66 versus 51) [34], suggesting age as a prognostic factor for the outcome of COVID-19 patients.

- Sex: SARS-CoV-2 has infected more men than women $(0.31 / 100,000$ versus $0.27 / 100,000)$, as described above [37].

- Comorbidities and complications: Patients with COVID-19 who require intensive care are more likely to suffer from acute cardiac injury and arrhythmia [34]. Cardiac events were also the main reason for death in SARS patients $[55,65,99]$. It has been reported that SARS-CoV-2 can also bind to ACE2-positive cholangiocytes, which might lead to liver dysfunctions in COVID-19 patients [100]. It is worth noting that age and underlying disease are strongly correlated and might interfere with each other [55].

- Abnormal laboratory findings: The C-reactive protein (CRP) level in blood reflects the severity of inflammation or tissue injury and has been proposed to be a potential prognostic factor for disease, response to therapy, and ultimate recovery [101]. The correlation of CRP level to the severity and prognosis of COVID-19 has also been proposed [101]. In addition, elevated lactate dehydrogenase (LDH), aspartate aminotransferase (AST), alanine aminotransferase (ALT), and creatine kinase (CK) may also help predict the outcome. These enzymes are expressed extensively in multiple organs, especially in the heart and liver, and are released during tissue damage [102,103]. Thus, they are traditional markers for heart or liver dysfunctions.

- Major clinical symptoms: Chest radiography and temporal progression of clinical symptoms should be considered together with the other issues for the prediction of outcomes and complications of COVID-19.

- Use of steroids: As described above, steroids are immunosuppressant commonly used as an adjunctive therapy for infectious diseases to reduce the severity of inflammatory damage [104]. Since a high dosage of corticosteroids was widely used in severe SARS patients, many survivors suffered from avascular osteonecrosis with life-long disability and poor life quality [105]. Thus, if needed, steroids should be used at low dosage and for a short time in COVID-19 patients.

- Mental stress: As described above, during the COVID-19 outbreak many patients have suffered from extraordinary stress as they often endured long periods of quarantine and extreme uncertainty and witnessed the death of close family members and fellow patients. It is imperative to provide psychological counseling and long-term support to help these patients recover from the stress and return to normal life [66].

\section{Prognosis of the epidemic}

According to demographic studies so far, COVID-19 seems to have different epidemiological features from SARS. In addition to replicating in the lower respiratory tract, SARS-CoV-2 can efficiently replicate in the upper respiratory tract and causes 
mild or no symptoms in the early phase of infection, similar to other CoVs that cause common colds [106]. Therefore, infected patients at the early phase or incubation period can produce a large amount of virus during daily activities, causing great difficulty for the control of the epidemic. However, the transmission of SARS-CoV was considered to occur when the patients are severely ill, while most transmission did not happen at the early phase [107]. Thus, the current outbreak of COVID-19 is much more severe and difficult to control than the outbreak of SARS.

Table 3. Prognostic factors for COVID-19 in comparison with SARS and MERS

\begin{tabular}{|c|c|c|c|c|}
\hline Disease & $\begin{array}{l}\text { Laboratory } \\
\text { results }\end{array}$ & $\begin{array}{l}\text { Chest } \\
\text { radiography }\end{array}$ & Others & Reference \\
\hline COVID-19 & $\begin{array}{c}\text { CRP } \\
\text { AST } \\
\text { ALT } \\
\text { CK } \\
\text { LDH } \\
\text { D-dimer } \\
\text { Lymphopenia }\end{array}$ & $\begin{array}{l}\text { Chest } \\
\text { radiography }\end{array}$ & $\begin{array}{c}\text { Age } \\
\text { Gender } \\
\text { Pregnancy } \\
\text { Viral load } \\
\text { Underlying } \\
\text { disease }\end{array}$ & \\
\hline SARS & $\begin{array}{c}\text { CRP } \\
\text { AST } \\
\text { ALT } \\
\text { CK } \\
\text { LDH } \\
\text { D-dimer } \\
\text { Low platelet } \\
\text { Plasma } \\
\text { electrolyte }\end{array}$ & $\begin{array}{l}\text { Chest } \\
\text { radiography }\end{array}$ & $\begin{array}{c}\text { Age } \\
\text { Gender } \\
\text { Pregnancy } \\
\text { Underlying } \\
\text { diseases }\end{array}$ & $\begin{array}{c}{[55,59,65,} \\
94]\end{array}$ \\
\hline MERS & $\begin{array}{l}\text { Neutrophilia } \\
\text { Lymphopenia } \\
\text { Serum } \\
\text { creatinine } \\
\text { LDH }\end{array}$ & $\begin{array}{l}\text { The diffuse or } \\
\text { brochopneumonia }\end{array}$ & $\begin{array}{c}\text { Age, } \\
\text { Chronic } \\
\text { kidney } \\
\text { disease, } \\
\text { Hypertension, } \\
\text { Viral load }\end{array}$ & [95-98] \\
\hline
\end{tabular}

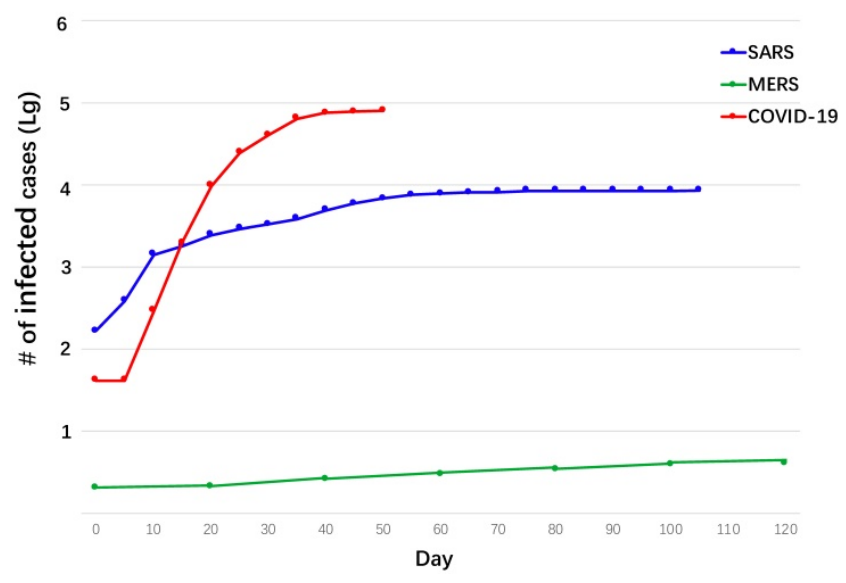

Figure 5. Comparison of epidemic of COVID-19, SARS, and MERS

Great efforts are currently underway in China including the lockdown of Wuhan and surrounding cities and continuous quarantine of almost the entire population in hopes of interrupting the transmission of SARS-CoV-2. Although these actions have been dramatically damaging the economy and other sectors of the country, the number of new patients is declining, indicating the slowdown of the epidemic. The most optimistic estimate is that the outbreak will end by March and the downswing phase will last for 3-4 months [108]. However, some other experts are not that optimistic. Paul Hunter, et al., estimated that COVID-19, which seems substantially more infectious than SARS, will not end in 2020 [109]. Ira Longini, et al., established a model to predict the outcome of the epidemic and suggested that SARS-CoV-2 could infect two-thirds of the global population [110].

A Canadian group reported that SARS-CoV-2 was detected in both mid-turbinate and throat swabs of patients who recovered and left the hospital 2 weeks earlier [111], which indicates that the newly identified virus could become a cyclical episode similar to influenza. However, promising signs have occurred in China based on the declining number of new cases, indicating the current strategies might have been working. Ebola was originally predicted to cause up to a million cases with half a million deaths. However, via strict quarantine and isolation, the disease has eventually been put under control [112, 113]. It is possible, similar to SARS-CoV, that SARSCoV-2 might become weaker in infectivity and eventually die down or become a less pathogenic virus co-existent with humans. A comparison of the epidemic of COVID-19 with that of SARS and MERS is provided below (Fig. 5).

\section{Prevention}

SARS-CoV-2 is highly transmittable through coughing or sneezing, and possibly also through direct contact with materials contaminated by the virus [12]. The virus was also found in feces, which raises a new possibility of feces-to-mouth transmission [114]. A recent study on 138 cases reported that $41 \%$ of the cases were possibly caused by nosocomial infections, including 17 patients with other prior diseases and 40 health-care providers [115]. Thus, great precaution should be used to protect humans, especially health-care providers, social workers, family members, colleagues, and even bystanders in contact with patients or infected people.

\section{Personal role}

The first line of defense that could be used to lower the risk of infection is through wearing face masks; both the use of surgical masks and N95 respirator masks (series \# 1860s) helps control the spread of viruses [116]. Surgical face masks prevent liquid droplets from a potentially infected individual 
from traveling through the air or sticking onto surfaces of materials, where they could be passed on to others [117]. However, only N95 (series \# 1860s) masks can protect against the inhalation of virions as small as 10 to $80 \mathrm{~nm}$, with only $5 \%$ of the virions being able to penetrate completely; SARS-CoV-2 is similar to SARS-CoV in size and both are approximately $85 \mathrm{~nm}$ [117]. Since particles can penetrate even five surgical masks stacked together, health-care providers in direct contact with patients must wear N95 (series \# 1860s) masks but not surgical masks [118].

In addition to masks, health-care providers should wear fitted isolation gowns in order to further reduce contact with viruses. Viruses can also infect an individual through the eyes. On January 22, 2020, a doctor was infected with SARS-CoV-2 although he wore an N95 mask; the virus might have entered his body through his inflammatory eyes [119]. Thus, health-care providers should also wear transparent face shields or goggles while working with patients.

For the general public in affected or potentially affected areas, it is highly suggested that everybody wash their hands with disinfectant soaps more often than usual, try to stay indoors for self-quarantine and limit contact with potentially infected individuals. Three feet is considered an appropriate distance for people to stay away from a patient [120]. These actions are effective methods to lower the risk of infection as well as prevent the spread of the virus.

\section{Governmental role}

Although SARS-CoV-2 came as a new virus to the human world, its high homology to SARS-CoV as reported on 7 January 2020 [3] should have caused high alert to China based on her deep memory of the SARS outbreak in 2003. However, not until 19 January 2020 did the director of the Center of Disease Control of Wuhan comfort the citizens by saying that the novel virus has low contagiousness and limited reproductivity from human to human and that it is not a problem to prevent and contain the disease. This message remarkably relaxed the alarm of the public, especially when the entire country was preparing for the Spring Festival, and the critical time was missed to contain the disease at its minimal scale in Wuhan.

The disease control agencies in China may take this hard lesson and make critical improvements in the future. For example, these agencies should be (1) more careful when making public announcements as every word counts to citizens and can change their attitude and decisions; (2) more sensitive and reactive to unusual information from clinics rather than waiting for formal reports from doctors or officials; (3) more restrictive to contain a potential epidemic at its early stage rather than attempting to comfort the public; and (4) more often to issue targeted and effective drills to increase the public's awareness about epidemic diseases and to test and improve the response system of the society periodically.

\section{Concluding remarks}

The outbreak of COVID-19 caused by the novel virus SARS-CoV-2 started in the end of December 2019. In less than two months, it has spread all over China and near 50 other countries globally at the time of this writing. Since the virus is very similar to SARS-CoV and the symptoms are also similar between COVID-19 and SARS, the outbreak of COVID-19 has created a sense of SARS recurring. However, there are some remarkable differences between COVID-19 and SARS, which are essential for containing the epidemic and treating the patients.

- COVID-19 affects more elderly individuals than youth and more men than women, and the severity and death rate are also higher in elderly individual than in youth.

- SARS has higher mortality than COVID-19 (10.91\% versus $1.44 \%$ ).

- COVID-19 patients transmit the virus even when they are symptomless whereas SARS patients do so usually when they are severely ill, which causes much greater difficulty to contain the spread of COVID-19 than SARS. This partially explains why SARS-CoV-2 spread much faster and broader than SARS-CoV.

- The regular RNA assay for SARS-CoV-2 can be negative in some COVID-19 patients. On the other hand, cured patients can be positive for the virus again. These findings dramatically increase the risk of virus spreading.

Given such rapid progress in research on COVID-19, several critical issues remain to be solved, as follows:

- Where did SARS-CoV-2 come from? Although 96\% genetic homolog was found between SARSCoV-2 and two bat SARS-like CoVs, we still cannot conclude that SARS-CoV-2 is from bats.

- What animal was the intermediate species to transmit the virus from the original host, say bats, to humans? Without knowing answers to \#1 and 2 , we cannot efficiently cut the transmission, and the outbreak can relapse at any time.

- Although molecular modeling and biochemical assays have demonstrated that SARS-CoV-2 binds to ACE2, how exactly does the virus enter the airway cells and cause subsequent pathological changes? Does the virus also bind ACE2-expressing cells in other organs [121]? 
Without clear answers to these questions, we cannot achieve fast and accurate diagnosis and effective treatment.

- How long will the epidemic last? How is the virus genetically evolving during transmission among humans? Will it become a pandemic worldwide, die down like SARS or relapse periodically like the flu?

It is essential but may take some time to search for answers to the above and many other questions. However, with whatever expense it may demand, we have no other choice but to stop the epidemic as soon as possible and bring our life back to normal.

\section{Acknowledgments}

This work was supported by University of Macau Research Committee funds MYRG \#2016-00070-FHS, and \#2017-00124-FHS, Macau Science and Technology Development Fund (FDCT) \#095/2017/A1 and 0112-2018-A3, and FDCTNational Natural Science Foundation of China joint grant \#0008-2019-AFJ to R.X.

\section{Author contributions}

Y.Y. and R.X. conceived and designed the manuscript. Y.Y., P.L., S.Y., E.L. and R.X. wrote the manuscript. R.X gave the final approval of the manuscript.

\section{Competing Interests}

R.X. is a founder of ImStem Biotechnology, Inc., a stem cell company. The other authors declare no competing financial interests.

\section{References}

1. Velavan TP, Meyer CG. The COVID-19 epidemic. Trop Med Int Health. 2020. DOI: https:// doi.org/10.1111/tmi.13383.

2. [Internet] NEWS A: WHO warns coronavirus, now dubbed COVID-19, is 'public enemy number 1 ' and potentially more powerful than terrorism. https://www.abc.net.au/news/2020-02-12/coronavirus-public-enemy-numb er-one-vaccine/11956446.

3. [Internet] Zhang Y-Z. Novel 2019 coronavirus genome. http://virological.org/t/novel-2019-coronavirus-genome/319.

4. de Wit E, van Doremalen N, Falzarano D, Munster VJ. SARS and MERS: recent insights into emerging coronaviruses. Nat Rev Microbiol. 2016; 14: 523-34.

5. Paules $\mathrm{CI}$, Marston HD, Fauci AS. Coronavirus Infections-More Than Just the Common Cold. JAMA. 2020. DOI:10.1001/jama.2020.0757

6. Wang C, Horby PW, Hayden FG, Gao GF. A novel coronavirus outbreak of global health concern. Lancet. 2020; 395:470-473

7. [Internet] CDC: 2019 Novel Coronavirus, Wuhan, China. https://www.cdc.gov/coronavirus/2019-ncov/index.html.

8. Guan W-j, Ni Z-y, Hu Y, Liang W-h, Ou C-q, He J-x, et al. Clinical Characteristics of Coronavirus Disease 2019 in China.N Engl J Med. 2020.DOI: 10.1056/NEJMoa2002032

9. [Internet] Reliefweb: Johns Hopki University. Coronavirus COVID-19 Global Cases by Johns Hopkins CSSE. https://reliefweb.int/report/world/ coronavirus-covid-19-global-cases-johns-hopkins-csse

10. Dong E, Du H, Gardner L. An interactive web-based dashboard to track COVID-19 in real time. The Lancet Infect Dis. 2020. DOI: 10.1016/S1473-3099(20)30120-1.

11. de Wilde AH, Snijder EJ, Kikkert M, van Hemert MJ. Host Factors in Coronavirus Replication. Curr Top Microbiol Immunol. 2018; 419: 1-42.

12. Raj VS, Mou H, Smits SL, Dekkers DH, Muller MA, Dijkman R, et al. Dipeptidyl peptidase 4 is a functional receptor for the emerging human coronavirus-EMC. Nature. 2013; 495: 251-4.
13. Sevajol M, Subissi L, Decroly E, Canard B, Imbert I. Insights into RNA synthesis, capping, and proofreading mechanisms of SARS-coronavirus. Virus Res. 2014; 194: 90-9.

14. Dong N, Yang X, Ye L, Chen K, Chan EW-C, Yang M, et al. 2020. Genomic and protein structure modelling analysis depicts the origin and infectivity of 2019-nCoV, a new coronavirus which caused a pneumonia outbreak in Wuhan, China. DOI: https://doi.org/10.1101/2020.01.20.913368

15. Xu X, Chen P, Wang J, Feng J, Zhou H, Li X, et al. 2020. Evolution of the novel coronavirus from the ongoing Wuhan outbreak and modeling of its spike protein for risk of human transmission. SCIENCE CHINA Life Sciences. Doi: https://doi.org/10.1007/s11427-020-1637-5

16. Lu R, Zhao X, Li J, Niu P, Yang B, Wu H, et al. Genomic characterisation and epidemiology of 2019 novel coronavirus: implications for virus origins and receptor binding. The Lancet. 2020. DOI: https://doi.org/10.1016/S0140-6736(20)30251-8.

17. Zhu N, Zhang D, Wang W, Li X, Yang B, Song J, et al. A Novel Coronavirus from Patients with Pneumonia in China, 2019. N Engl J Med. 2020. DOI:10.1056/NEJMoa2001017.

18. Letko M, Munster V. 2020. Functional assessment of cell entry and receptor usage for lineage B $\beta$-coronaviruses, including 2019-nCoV. bioRxiv. DOI: 10.1101/2020.01.22.915660.

19. Zhou P, Yang X-L, Wang X-G, Hu B, Zhang L, Zhang W, et al. 2020. Discovery of a novel coronavirus associated with the recent pneumonia outbreak in humans and its potential bat origin. bioRxiv. DOI: 10.1101/2020.01.22.914952.

20. Chan JF, Kok KH, Zhu Z, Chu KK, Yuan TS, Yuen KY, et al. Genomic characterization of the 2019 novel human-pathogenic coronavirus isolated from a patient with atypical pneumonia after visiting Wuhan. Emerg. Microb. Infect. 2020; 9:221-36.

21. Zhou Q, Yan R, Zhang Y, Li Y, Xia L. 2020. Structure of dimeric full-length human ACE2 in complex with B0AT1. bioRxiv. DOI: https://doi.org/10.1101/2020.02.17.951848.

22. Ji W, Wang W, Zhao X, Zai J, Li X. 2020. Homologous recombination within the spike glycoprotein of the newly identified coronavirus may boost cross-species transmission from snake to human. J Med Virol. DOI:10.1002/jmv.25682.

23. Xiao KP, Zhai JQ, Feng YY, Zhou N, Zhang X, Zou JJ, et al. 2020. Isolation and characterization of 2019-nCoV-like coronavirus from Malayan Pangolins. bioRxiv. DOI: http://doi.org/10.1101/2020.02.17.951335

24. Duan S-M, Zhao X-S, Wen R-F, Huang J-J, Pi G-H, Zhang S-X, et al. Stability of SARS coronavirus in human specimens and environment and its sensitivity to heating and UV irradiation. Biomed Environ Sci. 2003; 16: 246-55.

25. Geller C, Varbanov M, Duval RE. Human coronaviruses: insights into environmental resistance and its influence on the development of new antiseptic strategies. Viruses. 2012; 4: 3044-68.

26. Rabenau HF, Cinatl J, Morgenstern B, Bauer G, Preiser W, Doerr HW. Stability and inactivation of SARS coronavirus. Medical Microbiology and Immunology. 2004; 194: 1-6.

27. [Internet] NHC: Diagnosis and treatment of pneumonia caused by 2019 new coronavirus (trial version5).http://www.nhc.gov.cn/yzygj/s7652m/202002/e84bd30142ab4d8 982326326e4db22ea.shtml

28. Ben Addi A, Lefort A, Hua X, Libert F, Communi D, Ledent $C$, et al Modulation of murine dendritic cell function by adenine nucleotides and adenosine: involvement of the $\mathrm{A}(2 \mathrm{~B})$ receptor. European journal of immunology. 2008; 38: 1610-20.

29. Lu X, Pan J, Tao J, Guo D. SARS-CoV nucleocapsid protein antagonizes IFN-beta response by targeting initial step of IFN-beta induction pathway, and its C-terminal region is critical for the antagonism. Virus Genes. 2011; 42: $37-45$.

30. Mathern DR, Heeger PS. Molecules Great and Small: The Complement System. Clin J Am Soc Nephrol. 2015; 10: 1636-50.

31. Traggiai E, Becker S, Subbarao K, Kolesnikova L, Uematsu Y, Gismondo MR, et al. An efficient method to make human monoclonal antibodies from memory B cells: potent neutralization of SARS coronavirus. Nat Med. 2004; 10: 871-5.

32. Niu P, Zhang S, Zhou P, Huang B, Deng Y, Qin K, et al. Ultrapotent Human Neutralizing Antibody Repertoires Against Middle East Respiratory Syndrome Coronavirus From a Recovered Patient. J Infect Dis. 2018; 218: $1249-60$

33. Channappanavar R, Perlman S. Pathogenic human coronavirus infections: causes and consequences of cytokine storm and immunopathology. Seminars in Immunopathology. 2017; 39: 529-39.

34. Wang D, Hu B, Hu C, Zhu F, Liu X, Zhang J, et al. Clinical Characteristics of 138 Hospitalized Patients With 2019 Novel Coronavirus-Infected Pneumonia in Wuhan, China. JAMA. 2020. DOI:10.1001/jama.2020.1585

35. Li G, Fan $Y$, Lai $Y$, Han T, Li Z, Zhou P, et al. Coronavirus infections and immune responses. J Med Virol. 2020. DOI: https://doi.org/10.1002/ jmv.25685.

36. Li Q, Guan X, Wu P, Wang X, Zhou L, Tong Y, et al. Early Transmission Dynamics in Wuhan, China, of Novel Coronavirus-Infected Pneumonia. 2020. DOI:10.1056/NEJMoa2001316.

37. Yang Y, Lu Q, Liu M, Wang Y, Zhang A, Jalali N, et al.2020. Epidemiological and clinical features of the 2019 novel coronavirus outbreak in China. medRxiv. DOI: https://doi.org/10.1101/2020.02.10.20021675. 
38. Chang D, Lin M, Wei L, et al. Epidemiologic and Clinical Characteristics of Novel Coronavirus Infections Involving 13 Patients Outside Wuhan, China. JAMA. 2020. DOI:10.1001/jama.2020.1623.

39. Chen N, Zhou M, Dong X, Qu J, Gong F, Han Y, et al. 2020. Epidemiological and clinical characteristics of 99 cases of 2019 novel coronavirus pneumonia in Wuhan, China: a descriptive study. Lancet. DOI:10.1016/S0140-6736(20)30211-7.

40. Alexander E. Gorbalenya, Susan C. Baker, Ralph S. Baric, et al. 2020. Severe acute respiratory syndrome-related coronavirus: The species and its viruses a statement of the Coronavirus Study Group. medRxiv. DOI: https://doi.org/10.1101/2020.02.07.937862.

41. Ren LL, Wang YM, Wu ZQ, Xiang ZC, Guo L, Xu T, et al. 2020. Identification of a novel coronavirus causing severe pneumonia in human: a descriptive study. Chin Med J (Engl). DOI:10.1097/CM9.0000000000000722.

42. Huang C, Wang Y, Li X, et al. Clinical features of patients infected with 2019 novel coronavirus in Wuhan, China. Lancet. 2020; 6736: 1-10.

43. Rothe C, Schunk M, Sothmann P, Bretzel G, Froeschl G, Wallrauch C, et al. Transmission of 2019-nCoV Infection from an Asymptomatic Contact in Germany. N Engl J Med. 2020. DOI:10.1056/NEJMc2001468.

44. Phan LT, Nguyen TV, Luong QC, Nguyen TV, Nguyen HT, Le HQ, et al. Importation and Human-to-Human Transmission of a Novel Coronavirus in Vietnam. N Engl J Med. 2020. DOI:10.1056/NEJMc2001272.

45. Pan, Y., Guan, H. Imaging changes in patients with 2019-nCov. Eur Radiol . 2020. DOI: http://doi.org/10.1007/s00330-020-06713-z.

46. [Internet] WHO: Geneva, Switzerland. Summary of probable SARS cases with onset of illness from 1 Nvember 2002 to 31 July 2003.https://www.who.int/csr/sars/country/table2003_09_23/en/.

47. [Internet]WHO: MERS SITUATION UPDATE. http://applications.emro.who. int/docs/EMRPUB-CSR-241-2019-EN.pdf?ua=1\&ua=1\&ua=1.

48. Tang B, Wang X, Li Q, Bragazzi NL, Tang S, Xiao Y, et al. Estimation of the Transmission Risk of the 2019-nCoV and Its Implication for Public Health Interventions. J Clin Med. 2020; 9, 462.

49. [Internet]WHO: Consensus Document on the Epidemiology of SARS. Wkly Epidemiol Rec. 2003; 78: 373-5. https://www.who.int/csr/sars/en/ WHOconsensus.pdf

50. [Internet]WHO: Organizaition WH. Global Surveillance for human infection with novel coronavirus (2019-nCoV). https://www.who.int/publicationsdetail/global-surveillance-for-human-infection-with-novel-coronavirus-(2019 -ncov).

51. [Internet]CHANGDE-NHC: Epidemic

Bulletin. http://wjw.changde.gov.cn/zhdt/wjdt/content 720891.

52. Chen N, Zhou M, Dong X, Qu J, Gong F, Han Y, et al. Epidemiological and clinical characteristics of 99 cases of 2019 novel coronavirus pneumonia in Wuhan, China: a descriptive study. Lancet. 2020; 395: 507-13.

53. Gunther A, Ruppert C, Schmidt R, Markart P, Grimminger F, Walmrath D, et al. Surfactant alteration and replacement in acute respiratory distress syndrome. Respir Res. 2001; 2: 353-64.

54. Gralinski LE, Baric RS. Molecular pathology of emerging coronavirus infections. The Journal of pathology. 2015; 235: 185-95.

55. Wang JT, Sheng WH, Fang CT, Chen YC, Wang JL, Yu CJ, et al. Clinical manifestations, laboratory findings, and treatment outcomes of SARS patients. Emerg Infect Dis. 2004; 10: 818-24.

56. Zhe Xu, Lei Shi, Yijin Wang, Jiyuan Zhang, Lei Huang, Chao Zhang, et al. Pathological findings of COVID-19 associated with acute respiratory distress $\begin{array}{lllll}\text { syndrome } & \text { Lacet } & \text { 2020; }\end{array}$ DOI:https://doi.org/10.1016/S2213-2600(20)30076-X.

57. Ding Y, Wang H, Shen H, Li Z, Geng J, Han H, et al. The clinical pathology of severe acute respiratory syndrome (SARS): a report from China. The Journal of pathology. 2003; 200: 282-9.

58. Ng DL, Al Hosani F, Keating MK, Gerber SI, Jones TL, Metcalfe MG, et al. Clinicopathologic, Immunohistochemical, and Ultrastructural Findings of a Fatal Case of Middle East Respiratory Syndrome Coronavirus Infection in the United Arab Emirates, April 2014. The American journal of pathology. 2016; 186: 652-8.

59. Chang SC. Clinical findings, treatment and prognosis in patients with severe acute respiratory syndrome (SARS). J Chin Med Assoc. 2005; 68: 106-7.

60. [Internet] Zhang F, OOA, JSG. A protocol for detection of COVID-19 using CRISPR

diagnostics.https://www.broadinstitute.org/files/publications/special/CO VID-19\%20detection\%20(updated).pdf.

61. [Internet] BLOOMBERG: China Seeks Plasma From Recovered Patients as Virus Treatment. https://time.com/5784286/covid-19-chinaplasma-treatment/.

62. [Internet] WIRED: NIILER E. Darpa Cranks Up Antibody Research to Stall Coronavirus. https://www.wired.com/story/darpa-cranks-up-antibodyresearch-to-stall-coronavirus/.

63. Majeski EI, Harley RA, Bellum SC, London SD, London L. Differential role for $\mathrm{T}$ cells in the development of fibrotic lesions associated with reovirus 1/L-induced bronchiolitis obliterans organizing pneumonia versus Acute Respiratory Distress Syndrome. Am J Respir Cell Mol Biol. 2003; 28: 208-17.

64. Holshue ML, DeBolt C, Lindquist S, Lofy KH, Wiesman J, Bruce H, et al. First Case of 2019 Novel Coronavirus in the United States. N Engl J Med. 2020. DOI:10.1056/NEJMoa2001191.
65. Booth CM, Matukas LM, Tomlinson GA, Rachlis AR, Rose DB, Dwosh HA, et al. Clinical features and short-term outcomes of 144 patients with SARS in the greater Toronto area. JAMA. 2003; 289: 2801-9.

66. Xiang YT, Yang Y, Li W, Zhang L, Zhang Q, Cheung T, et al. Timely mental health care for the 2019 novel coronavirus outbreak is urgently needed. Lancet Psychiatry. 2020; DOI: https://doi.org/10.1016/S2215-0366(20)30046-8.

67. Tisoncik JR, Korth MJ, Simmons CP, Farrar J, Martin TR, Katze MG. Into the eye of the cytokine storm. Microbiol Mol Biol Rev. 2012; 76: 16-32.

68. Lee DW, Gardner R, Porter DL, Louis CU, Ahmed N, Jensen M, et al. Current concepts in the diagnosis and management of cytokine release syndrome. Blood. 2014; 124: 188-95.

69. Behrens EM, Koretzky GA. Review: Cytokine Storm Syndrome: Looking Toward the Precision Medicine Era. Arthritis Rheumatol. 2017; 69: 1135-43.

70. Shimabukuro-Vornhagen A, Godel P, Subklewe M, Stemmler HJ, Schlosser HA, Schlaak M, et al. Cytokine release syndrome. J Immunother Cancer. 2018; 6: 56 .

71. L K, EM L, TB K, EB D, NL B, BT K, et al. Suppressor of cytokine signaling 4 (SOCS4) protects against severe cytokine storm and enhances viral clearance during influenza infection. PLoS pathogens. 2014; 10: e1004134.

72. Li N, Zhao D, Kirschbaum M, Zhang C, Lin CL, Todorov I, et al. HDAC inhibitor reduces cytokine storm and facilitates induction of chimerism that reverses lupus in anti-CD3 conditioning regimen. Proc Natl Acad Sci U S A. 2008; 105: 4796-801.

73. Clark D Russell JEM, J Kenneth Baillie. Clinical evidence does not support corticosteroid treatment for 2019-nCoV lung injury. Lancet. 2020. DOI: https://doi.org/10.1016/S0140-6736(20)30317-2

74. Griffith JF, Antonio GE, Kumta SM, Hui DSC, Wong JKT, Joynt GM, et al. Osteonecrosis of hip and knee in patients with severe acute respiratory syndrome treated with steroids. Radiology. 2005; 235: 168-75.

75. Shang L, Zhao J, Hu Y, Du R, Cao B. On the use of corticosteroids for 2019-nCoV pneumonia. The 2020. DOI:https://doi.org/10.1016/S0140-6736(20)30361-5

76. Warren TK, Jordan R, Lo MK, Ray AS, Mackman RL, Soloveva V, et al. Therapeutic efficacy of the small molecule GS-5734 against Ebola virus in rhesus monkeys. Nature. 2016; 531: 381-5.

77. Lo MK, Jordan R, Arvey A, Sudhamsu J, Shrivastava-Ranjan P, Hotard AL, et al. GS-5734 and its parent nucleoside analog inhibit Filo-, Pneumo-, and Paramyxoviruses. Sci Rep. 2017; 7: 43395.

78. Sheahan TP, Sims AC, Graham RL, Menachery VD, Gralinski LE, Case JB, et al. Broad-spectrum antiviral GS-5734 inhibits both epidemic and zoonotic coronaviruses. Sci Transl Med. 2017; 9

79. [Internet] The New York Times: Denise Grady. China Begins Teating an Antiviral Drug in Coronavirus Patients. https://www.nytimes.com/2020/ 02/06/health/coronavirus-treatments.html

80. Hirsch $\mathrm{HH}$, Martino R, Ward KN, Boeckh M, Einsele H, Ljungman P. Fourth European Conference on Infections in Leukaemia (ECIL-4): guidelines for diagnosis and treatment of human respiratory syncytial virus, parainfluenza virus, metapneumovirus, rhinovirus, and coronavirus. Clin Infect Dis. 2013; 56: 258-66.

81. Zumla A, Chan JF, Azhar EI, Hui DS, Yuen KY. Coronaviruses - drug discovery and therapeutic options. Nat Rev Drug Discov. 2016; 15: 327-47.

82. Etzioni A, Ochs HD. Primary Immunodeficiency Disorders: A Historic and Scientific Perspective: Elsevier Science. USA: Academic Press; 2014.

83. Kreil TR, Farcet MR. Immunoglobulins and virus antibody titers: of past needs, current requirements, and future options. Transfusion. 2018; 58 (Suppl 3): 3090-5.

84. Lee DW, Gardner R, Porter DL, Louis CU, Ahmed N, Jensen M, et al. Current concepts in the diagnosis and management of cytokine release syndrome. Blood. 2014; 124: 188-95.

85. [Internet] Korea Biomedical Review: Song S. Traditional Chinese medicine harmed new coronavirus control.http://www.koreabiomed.com/ news/articleView.html?idxno $=7370$

86. Lu H. Drug treatment options for the 2019-new coronavirus (2019-nCoV). Biosci Trends. 2020:10-12.

87. [Internet] DXY.cn: COVIND-19 Epidemic Situation in Real Time. 2020; https://ncov.dxy.cn/ncovh5/view/pneumonia.

88. Xia WG, An CQ, Zheng CJ, Zhang JX, Huang M, Wang Y, et al. Clinical study on 34 cases of COVID-19 treated with combined traditional Chinese and western medicine (in Chinese). Journal of Tranditional Chinese Medicine. 2020; $1-7$

89. Cheung YT, Chau PH, Yip PSF. A revisit on older adults suicides and Severe Acute Respiratory Syndrome (SARS) epidemic in Hong Kong. Int J Geriatr Psychiatry. 2008; 23: 1231-8.

90. Su T-P, Lien T-C, Yang C-Y, Su YL, Wang J-H, Tsai S-L, et al. Prevalence of psychiatric morbidity and psychological adaptation of the nurses in a structured SARS caring unit during outbreak: a prospective and periodic assessment study in Taiwan. J Psychiatr Res. 2007; 41: 119-30.

91. Du L, He Y, Zhou Y, Liu S, Zheng BJ, Jiang S. The spike protein of SARS-CoV--a target for vaccine and therapeutic development. Nat Rev Microbiol. 2009; 7: 226-36.

92. Roper RL, Rehm KE. SARS vaccines: where are we? Expert Rev. Vaccines. 2009; 8: 887-98.

93. Xu J, Jia W, Wang P, Zhang S, Shi X, Wang X, et al. Antibodies and vaccines against Middle East respiratory syndrome coronavirus. Emerg Microbes Infect. 2019; 8: 841-56. 
94. Peiris JS, Chu CM, Cheng VC, Chan KS, Hung IF, Poon LL, et al. Clinical progression and viral load in a community outbreak of coronavirus-associated SARS pneumonia: a prospective study. Lancet. 2003; 361: 1767-72.

95. Alraddadi B, Bawareth N, Omar H, Alsalmi H, Alshukairi A, Qushmaq I, et al. Patient characteristics infected with Middle East respiratory syndrome coronavirus infection in a tertiary hospital. Ann Thorac Med. 2016; 11: 128-31.

96. Garbati MA, Fagbo SF, Fang VJ, Skakni L, Joseph M, Wani TA, et al. A Comparative Study of Clinical Presentation and Risk Factors for Adverse Outcome in Patients Hospitalised with Acute Respiratory Disease Due to MERS Coronavirus or Other Causes. PloS one. 2016; 11: 1-12.

97. Momattin H, Mohammed K, Zumla A, Memish ZA, Al-Tawfiq JA. Therapeutic options for Middle East respiratory syndrome coronavirus (MERS-CoV)--possible lessons from a systematic review of SARS-CoV therapy. Int J Infect Dis. 2013; 17: e792-8.

98. Hwang SM, Na BJ, Jung Y, Lim HS, Seo JE, Park SA, et al. Clinical and Laboratory Findings of Middle East Respiratory Syndrome Coronavirus Infection. Jpn J Infect Dis. 2019; 72: 160-7.

99. Cowling BJ, Muller MP, Wong IO, Ho LM, Lo SV, Tsang T, et al. Clinical prognostic rules for severe acute respiratory syndrome in low- and high-resource settings. Arch Intern Med. 2006; 166: 1505-11.

100. Chai X, Hu L, Zhang Y, Han W, Lu Z, Ke A, et al. 2020. Specific ACE2 Expression in Cholangiocytes May Cause Liver Damage After 2019-nCoV Infection. bioRxiv. DOI:10.1101/2020.02.03.931766

101. Johnson HL, Chiou CC, Cho CT. Applications of acute phase reactants in infectious diseases. J Microbiol Immunol Infect. 1999; 32: 73-82.

102. Wrenger C, Muller IB, Silber AM, Jordanova R, Lamzin VS, Groves MR. Aspartate aminotransferase: bridging carbohydrate and energy metabolism in Plasmodium falciparum. Curr Drug Metab. 2012; 13: 332-6.

103. Stankovic Stojanovic K, Lionnet F. Lactate dehydrogenase in sickle cell disease. Clinica chimica acta; international journal of clinical chemistry. 2016; 458: 99-102.

104. Cheung CY, Poon LL, Lau AS, Luk W, Lau YL, Shortridge KF, et al. Induction of proinflammatory cytokines in human macrophages by influenza A (H5N1) viruses: a mechanism for the unusual severity of human disease? Lancet. 2002; 360: 1831-7.

105. Hong N, Du XK. Avascular necrosis of bone in severe acute respiratory syndrome. Clinical radiology. 2004; 59: 602-8.

106. Chan JF, Yuan S, Kok KH, To KK, Chu H, Yang J, et al. A familial cluster of pneumonia associated with the 2019 novel coronavirus indicating person-to-person transmission: a study of a family cluster. Lancet. 2020. 395:514-523

107. Peiris JS, Yuen KY, Osterhaus AD, Stohr K. The severe acute respiratory syndrome. N Engl J Med. 2003; 349: 2431-41.

108. [Internet] Terence:Rubin, Baden. Reality and Future about COVID-19. https://mp.weixin.qq.com/s/o3Dd61yN0GtdosCtrD-CrQ.

109. [Internet] ALJAZEERA: Casey R. How long will COVID-19 outbreak last; how can you stay protected? https://www.aljazeera.com/news/ 2020/02/long-covid-19-outbreak-stay-protected-200212140216674.html

110.[Internet] BLOOMBERG: Lauerman J. Coronavirus Could Infect Two-Thirds of Globe, Research Shows. https://www.bloomberg.com/news/ articles/2020-02-13/coronavirus-could-infect-two-thirds-of-globe-researchersays.

111. Silverstein WK, Stroud L, Cleghorn GE, Leis JA. First imported case of 2019 novel coronavirus in Canada, presenting as mild pneumonia. Lancet (London, England). 2020; 6736(20): 30370

112. Bradol JH. Ebola, the Day after. Rev Prat. 2017; 67: 841-4.

113. Waheed Y, Malik S, Khan M, Najmi MH. The World after Ebola: An Overview of Ebola Complications, Vaccine Development, Lessons Learned, Financial Losses, and Disease Preparedness. Crit Rev Eukaryot Gene Expr. 2019; 29: 77-84.

114. [Internet] Sciencealert: Latest Study Suggests The New Coronavirus Is Also Spreading Via Feces. https://www.sciencealert.com/latest-coronavirusstudy-suggests-it-can-also-be-spread-through-poop.

115. Wang D, Hu B, Hu C, Zhu F, Liu X, Zhang J, et al. Clinical Characteristics of 138 Hospitalized Patients With 2019 Novel Coronavirus-Infected Pneumonia in Wuhan, China. JAMA. 2020. DOI:10.1001/jama.2020.1585.

116. Johnson DF, Druce JD, Birch C, Grayson ML. A quantitative assessment of the efficacy of surgical and N95 masks to filter influenza virus in patients with acute influenza infection. Clin Infect Dis. 2009; 49: 275-7.

117. Balazy A, Toivola M, Adhikari A, Sivasubramani SK, Reponen T, Grinshpun SA. Do N95 respirators provide $95 \%$ protection level against airborne viruses, and how adequate are surgical masks? Am J Infect Control. 2006; 34: 51-7.

118. Derrick JL, Gomersall CD. Protecting healthcare staff from severe acute respiratory syndrome: filtration capacity of multiple surgical masks. J Hosp Infect. 2005; 59: 365-8.

119. Lu CW, Liu XF, Jia ZF. 2019-nCoV transmission through the ocular surface must not be ignored. Lancet. 2020. https://doi.org/10.1016/S01406736(20)303135.

120. [Internet]CDC: Guideline for Isolation Precautions: Preventing Transmission of Infectious Agents in Healthcare Settings (2007). https://stacks.cdc.gov/ view/cdc/61187.

121. Fan C, Li K, Ding Y, Lu WL, Wang J. 2020. ACE2 Expression in Kidney and Testis May Cause Kidney and Testis Damage After 2019-nCoV Infection. medRxiv. DOI: 10.1101/2020.02.12.20022418 